\title{
Gegar Vaganza: Persepsi Pengguna dan Penempatan Produk D'Herbs Dalam RANCANGAN ReALItI TeleVisyen DI MALAYSiA
}

\author{
Farah Farhanah Hishamudin \\ Universiti Sains Malaysia \\ farahfarhanah@student.usm.my \\ Nur Atikah A Rahman \\ Universiti Sains Malaysia \\ atikaharahman@usm.my
}

\section{ABSTRACT \\ GEGAR VAGANZA: CONSUMER PERCEPTION AND D'HERBS PRODUCT PLACEMENT IN REALITY TELEVISION SHOWS IN MALAYSIA}

\begin{abstract}
This study examines the types of product placements used in the television show Gegar Vaganza, particularly in its 5th season and looks at the consumer perceptions on the product placements used by D'Herbs Holdings Sdn. Bhd. Qualitative content analysis and in-depth interviews were conducted on eight respondents. The saturation of advertisements in the market has prompted marketers to turn to media product placement to deliver messages to the audiences more effectively. This study found that integrated implicit product placement received positive feedback on the process of recalling a brand or product. On the other hand, integrated explicit placements received positive perceptions in increasing the level of consumer information, however, received negative perceptions towards consumer purchasing intentions.
\end{abstract}

Keywords: D'Herbs, product placement, consumer's perception, perception process model, Gegar Vaganza, Elaboration Likelihood Model, Malaysia

\section{PENGENALAN}

Dengan wujudnya pelbagai saluran media dan jenis pengiklanan dalam pasaran, sedikit sebanyak kemunculannya mengganggu kehidupan seharian pengguna (Gritten, 2007). Lambakan pengiklanan menyebabkan pengguna tidak tertarik dengan iklan yang dipaparkan dan mudah beralih pandangan kepada perkara yang lain. Keadaan ini menyebabkan berlakunya pengelakan pengiklanan yang mendorong pengguna dengan sengaja menghindari iklan (Speck \& Elliott, 1997). Maka, pengiklan sewajarnya mencari penyelesaian alternatif 
dan kreatif untuk menyampaikan mesej pemasaran kepada pengguna. Salah satu alternatif menarik berbanding penggunaan iklan televisyen secara tradisional dan bentuk-bentuk komunikasi pemasaran yang lain adalah melalui penajaan televisyen (D'Astous \& Seguin, 1999).

Woelke dan Steininger (2008) menyatakan bahawa perubahan dalam kandungan media hari ini semakin meningkat dan menjadikan sempadan antara mesej editorial dengan komersial semakin kabur. Kebanyakan organisasi sengaja menggabungkan jenama, produk dan mesej pemujukan ke dalam kandungan media seperti filem, rancangan televisyen, permainan video dan sebagainya melalui penempatan jenama dan produk (Van Reijmersdal, Smit \& Neijens, 2010). Proses ini berlaku dengan cara mengintegrasikan sesuatu jenama atau produk agar menjadi sebahagian daripada rancangan dan memainkan peranan yang penting dalam jalan cerita dan perkembangan kreatifnya (Cain, 2011). Konsep penempatan produk merupakan taktik promosi yang menggunakan produk komersial sebenar dalam media fiksyen dan bukan fiksyen untuk meningkatkan minat pengguna terhadap sesuatu produk (Gutnik et al., 2007).

Di Malaysia, trend meletakkan produk dalam filem tempatan adalah sangat kurang jika dibandingkan dengan filem-filem antarabangsa. Hal ini kerana, filem-filem tempatan kurang mendapat sambutan daripada masyarakat (Imang, 2015). Justeru, penempatan produk dalam filem jarang mendapat sambutan oleh para pengiklan. Imang (2015) menyatakan, kutipan kasar tayangan filem tempatan daripada keseluruhan kutipan kasar tayangan filem di pawagam Malaysia adalah sekitar 16\%, berbanding $68.15 \%$ yang diperoleh filem luar negara atau berbahasa Inggeris pada tahun 2012. Selari dengan kenyataan van Zyl (2016), penempatan produk adalah berbeza mengikut negara yang bergantung pada budaya dan peraturan yang digunakan. Maka, dapat disimpulkan bahawa masyarakat di Malaysia lebih cenderung untuk menonton filem keluaran luar negara berbanding tempatan.

Oleh sebab filem tempatan kurang mendapat sambutan oleh masyarakat, trend pemasaran industri kreatif mula memfokuskan pengiklanan jenama dan produk dalam rancangan realiti televisyen. Trend meletakkan jenama dalam siri dan rancangan televisyen dilihat semakin mendapat sambutan dalam kalangan pengiklan. Sebagai contoh, drama bersiri Pujaan Hati Kanda yang ditayangkan di TV3 berjaya meraih sebanyak 12 juta penonton sejak disiarkan pada 20 Disember 2018 (Hanisah, 2019). Drama ini ditaja oleh produk Flavettes Effervescent Glow dan memainkan peranan yang aktif kerana digunakan oleh watak drama tersebut dalam beberapa adegan (Flavettes Malaysia, 2018). Kini, semakin banyak rancangan realiti televisyen yang mengaut keuntungan melalui penajaan dengan meletakkan jenama atau produk ke dalam kandungan kreatif.

Selain itu, terdapat beberapa contoh penempatan produk sama ada secara aktif mahupun pasif. Antaranya termasuklah Mentor Milenia 2016 yang ditaja oleh Vida Beauty (Baharom, 2016) dan Maharaja Lawak Mega 2018 yang ditaja oleh OPPO, KFC dan Adabi (Shikin et al., 2018). Antara aspek yang menarik adalah penempatan produk tidak hanya berlaku sekali tetapi penonton berhadapan dengan jenama atau produk yang diletakkan beberapa kali dalam episod tertentu dan sepanjang musim rancangan itu berlangsung (Suhrbier \& Behring, 2016). Tambahan lagi, penonton rancangan realiti televisyen akan cenderung untuk menonton lebih daripada satu episod. Justeru, mereka tidak mahu ketinggalan ataupun mempunyai keinginan yang tinggi untuk mengetahui siapa yang bakal muncul sebagai pemenang dalam pertandingan tersebut (Suhrbier \& Behring, 2016). 
Secara umum, kajian-kajian lepas mengenai penempatan produk di Malaysia adalah tentang impak penempatan jenama dan bagaimana penonton dapat mengingat kembali jenama dalam filem (Bamini et al., 2012), tingkah laku pengguna (Liew \& Lim 2014; Nurul Hanani et al., 2017) serta kesedaran penempatan produk (Mohd. Amir \& Shahrel, 2018). Oleh itu, kajian berkenaan penempatan produk dalam konteks Malaysia sangat diperlukan terutama yang berfokus pada jenis-jenis penempatan produk yang digunakan dalam rancangan realiti televisyen di Malaysia dan maklum balas pengguna terhadap penempatan produk yang digunakan.

Dengan melaksanakan penyelidikan mengenai penempatan produk, agensi pengiklanan, pemasar serta organisasi bakal mendapat manfaat tertentu. Misalnya, organisasi tertentu bakal mendapat panduan dalam usaha mengenal pasti jenis-jenis penempatan produk yang boleh digunakan untuk mendapatkan persepsi yang positif dari penggunaan penempatan produk. Kajian lepas menunjukkan penempatan produk yang agresif akan menyebabkan persepsi negatif terhadap produk tersebut (D'Astous \& Seguin, 1999). Gupta dan Lord (1998) membincangkan bahawa jenis penempatan produk mempunyai impak yang signifikan terhadap pengiktirafan penonton. Justeru, kajian ini bertujuan untuk mengenal pasti jenisjenis penempatan produk yang digunakan dalam rancangan realiti televisyen di Malaysia khususnya dalam program Gegar Vaganza musim ke-5. Kajian ini turut dilakukan bagi meneliti persepsi pengguna terhadap penempatan produk yang digunakan dalam Gegar Vaganza musim ke-5 yang dapat membantu pengiklan dan organisasi dalam mendapatkan maklumat yang berguna tentang kesesuaian penempatan produk dalam rancangan televisyen.

\section{ULASAN KAJIAN LEPAS}

Banyak kajian lepas dilakukan berkenaan penempatan produk. Oleh itu, pada bahagian ini, ulasan berkenaan kajian yang berfokus pada perkaitan antara jenama dengan rancangan televisyen dan penajaan dalam rancangan televisyen.

\section{Penempatan Produk: Perkaitan antara Jenama Produk dengan Rancangan Televisyen}

Kuhn (2008) menyatakan penempatan produk merupakan satu bentuk komunikasi pemasaran sama ada berbayar atau tidak berbayar, iaitu mesej mengenai produk, perkhidmatan, jenama, organisasi, individu atau idea yang dimasukkan ke dalam kandungan seperti filem, rancangan televisyen, muzik, permainan video dan sebagainya. Kajian awal mengenai penempatan produk telah mengkaji jenis penempatan produk di dalam media dan reaksi pengguna terhadapnya. Misalnya D'Astous dan Seguin (1999) menyatakan bahawa penempatan produk yang lebih menonjol dalam penajaan televisyen membuatkan penilaian pengguna menjadi lebih negatif walaupun bukan pengantara yang signifikan terhadap penilaian pengguna kerana kesan penempatan produk juga bergantung kepada jenis rancangan.

Selain itu, Brennan, Dubas dan Babin (1999) telah menilai sejauh mana masa pendedahan dan jenis penempatan produk dapat menerangkan kadar penonton mengenali jenama yang diletakkan dalam filem. Ini sejajar dengan Gupta dan Lord (1998) yang menyatakan jenis penempatan produk mempunyai impak yang signifikan terhadap pengiktirafan penonton. Antara jenis penempatan produk yang dikenal pasti ialah implisit, eksplisit bersepadu dan bukan eksplisit bersepadu (D'Astous \& Seguin, 1999). Penempatan produk implisit adalah penempatan produk yang pasif di dalam sesebuah rancangan televisyen, filem atau siri 
drama tetapi tidak dipaparkan secara rasmi. Jenis penempatan produk ini tidak memaparkan kelebihan dan kebaikan produk dalam kandungan media. Selain itu, penempatan produk eksplisit bersepadu ialah penempatan jenama atau logo yang dipaparkan secara aktif dan rasmi dalam rancangan. Penempatan jenama ini mempamerkan kelebihan dan kebaikan produk dengan jelas dalam kandungan media. Di samping itu, penempatan produk bukan eksplisit bersepadu adalah apabila jenama atau logo ditunjukkan dari permulaan, pertengahan dan akhir rancangan tetapi tidak digabungkan dalam rancangan.

Campbell, Mohr dan Verlegh (2007) pula menegaskan penempatan produk membawa kesedaran dan sikap yang tinggi terhadap jenama yang diletakkan. Hal ini bertentangan dengan pandangan Van Reijmersdal, Tutaj dan Boerman (2013) yang memfokuskan keraguan dan ingatan terhadap sesebuah jenama. Mereka melihat bahawa pendedahan penajaan tidak seharusnya wujud dalam filem tetapi diletakkan sebelum sesebuah filem itu bermula. Dengan peningkatan pendedahan penempatan jenama pada masa kini dalam filem mahupun televisyen, ini akan mewujudkan perasaan tidak senang dalam kalangan penonton.

Tambahan lagi, Karisik (2014) mendapati kebanyakan sarjana mengkaji keberkesanan penempatan produk dalam televisyen dengan melihat kelaziman, sifat dan ciri-ciri perletakan dalam televisyen. Kajian lepas turut meninjau keberkesanan penempatan jenama dalam televisyen melalui sikap dan ingatan pengguna (Karisik, 2014). Kaedah yang paling kerap digunakan adalah dengan menayangkan keseluruhan atau sedutan pendek dari penempatan produk yang dilakukan kepada sampel. Ini diikuti dengan soal selidik yang meneliti pengulangan, tahap pengiktirafan atau sikap terhadap penempatan produk (Law \& Braun, 2000; Tiwsakul, Hackley \& Szmigin, 2005; Van Reijmersdal et al., 2007; Cowley \& Barron, 2008; Homer, 2009). Dapatan kajian keberkesanan strategi penempatan jenama juga mendedahkan produk yang diletakkan secara visual sahaja paling kurang diingat semula tetapi lebih disukai oleh para penonton manakala produk yang diletakkan ditengah-tengah plot paling banyak diingat semula tetapi tidak disukai oleh para penonton.

Selain itu, Van Reijmersdal, Neijens dan Smit (2007) menjelaskan bahawa kekerapan pendedahan penempatan jenama melalui televisyen memberi kesan terhadap imej jenama. Bagi yang menonton rancangan televisyen lebih dari dua episod, penonton akan lebih cenderung untuk bersetuju dengan imej program. Sebaliknya, produk yang diletakkan dan ditayangkan berulang kali memberikan pengaruh yang negatif terhadap sikap pengguna berbanding dengan produk yang diletakkan secara halus (Suhrbier \& Behring, 2016).

Di Malaysia, kajian penempatan produk memfokuskan kepada penempatan produk dalam filem dan faktor individu itu sendiri. Bamini et al. (2012) menyatakan bahawa rakyat Malaysia mempunyai tahap penerimaan dan ingatan yang tinggi terhadap jenama serta memberikan impak yang ketara terhadap corak tingkah laku. Hasil kajian ini selaras dengan Nurul Hanani et al. (2017) yang mendapati rakyat Malaysia sedar akan penempatan produk yang terdapat dalam filem dan ini mempengaruhi keputusan pengguna. Liew dan Lim (2014) pula menunjukkan kepercayaan pengguna terhadap penempatan produk akan mempengaruhi sikap mereka sekiranya kepercayaan terhadap produk yang diletakkan adalah negatif, maka sikap yang negatif juga akan terhasil. Selain itu, niat pembelian akan dilakukan berdasarkan ciri fungsi yang terdapat pada produk yang dipaparkan. 


\section{Penajaan dalam Rancangan Televisyen}

Gabungan yang disengajakan oleh jenama, produk dan mesej pemujukan ke dalam kandungan editorial bukan komersial merupakan kandungan yang ditaja (Van Reijmersdal et al., 2007). Penajaan melibatkan bayaran dari penaja kepada entiti yang ditaja dan seterusnya memperoleh hak untuk mengaitkan ia dengan aktiviti seperti rancangan realiti televisyen dan untuk memasarkan perkaitan yang wujud (Cornwell \& Maignan, 1998). Kini, penajaan merupakan perkongsian dua hala yang saling menguntungkan antara penaja dan entiti yang ditaja dan memberi kesan kepada imej sesebuah organisasi (Allen, 2010). Menurut Koekemoer (2004), aktiviti ini merupakan kegiatan komunikasi pemasaran yang mana penaja secara kontrak memberikan bantuan dari segi kewangan atau lain kepada organisasi atau individu sebagai balasan untuk mendapatkan hak menggunakan nama penaja (syarikat, produk, jenama) dan logo dalam aktiviti yang ditaja. Penaja ingin mempengaruhi persepsi pengguna terhadap jenama atau produk dan membina imej positif untuk sesebuah organisasi (Erdogan \& Kitchen, 1998).

Pendedahan penajaan terhadap penonton mampu mengurangkan kesedaran ke atas jenama dan mengubah sikap terhadap sesebuah jenama, yang bergantung pada masa ia ditayangkan dalam rancangan televisyen (Campbell et al., 2007). Bukan itu sahaja, Boerman et al. (2013) menyatakan bahawa pendedahan penajaan mempengaruhi pengguna dalam memproses maklumat dan sikap pengetahuan pemujukan serta bergantung kepada tempoh pendedahan kepada penonton. Keadaan ini jelas menunjukkan bahawa pendedahan penajaan dapat meningkatkan kesan yang diinginkan seperti meningkatkan pengetahuan pemujukan dan mempengaruhi tanggapan terhadap sesebuah jenama.

Seterusnya Boerman et al. (2014) menambah bahawa pendedahan penajaan yang ditayangkan sebelum ataupun serentak dengan kandungan yang ditaja membuatkan penonton mengenali kandungan itu sebagai pengiklanan dan seterusnya memberikan masa yang mencukupi untuk melindungi diri mereka dari pemujukan. Oleh itu, mereka juga akan memproses kandungan yang ditaja secara kritikal dan akhirnya akan menjurus kepada sikap yang kurang menggalakkan terhadap jenama.

\section{KERANGKA TEORI}

Kajian ini menggunakan Model Kemungkinan Penguraian (Elaboration Likelihood Model (ELM)) oleh Petty dan Cacioppo (1986) dan Model Proses Persepsi (Solomon et al., 2013) untuk memahami persepsi pengguna terhadap penempatan produk..

\section{Model Kemungkinan Penguraian}

Model ini diadaptasi untuk memahami proses pemujukan yang berlaku melalui pendedahan penempatan produk dalam Gegar Vaganza musim ke-5 untuk mengenal pasti persepsi pengguna terhadapnya (Sila lihat Rajah 1). Model ini menerangkan bagaimana sikap boleh dibentuk dan diubah dengan cara yang berbeza melalui rangsangan yang diterima. Melalui model ini, kajian ini dapat memahami bagaimana rangsangan tersebut diproses, digunakan serta dijana oleh individu supaya perubahan sikap boleh berlaku.

Secara spesifiknya, ELM mempunyai dua prinsip penting iaitu dua laluan proses pemujukan yang dikenali sebagai central dan peripheral (Suhrbier \& Behring, 2016). Proses pemujukan ini akan berlaku berdasarkan kepada motivasi dan keupayaan seseorang individu 
yang kemudiannya akan menentukan tahap kemungkinan penguraian secara berterusan iaitu daripada penglibatan yang rendah kepada penglibatan yang tinggi (Petty \& Cacioppo, 1986). Selain itu, terdapat beberapa faktor yang mempengaruhi tahap kemungkinan penguraian individu, antaranya ialah penglibatan perkaitan peribadi, mesej yang mendalam, keperluan untuk kognisi dan sama ada kedudukan yang disokong atau tidak (Petty \& Cacioppo, 1986). Proses central berlaku apabila individu berada pada tahap penglibatan kognitif yang tinggi dengan pemikiran dan pengetahuan yang tinggi mengenai sesuatu isu. Proses peripheral pula berlaku apabila individu berada pada tahap penglibatan kognitif yang rendah, tahap penglibatan afektif yang tinggi dan disertai dengan tahap pemikiran dan pengetahuan yang kurang (Suraini, Hasrina \& Bahiyah, 2014).

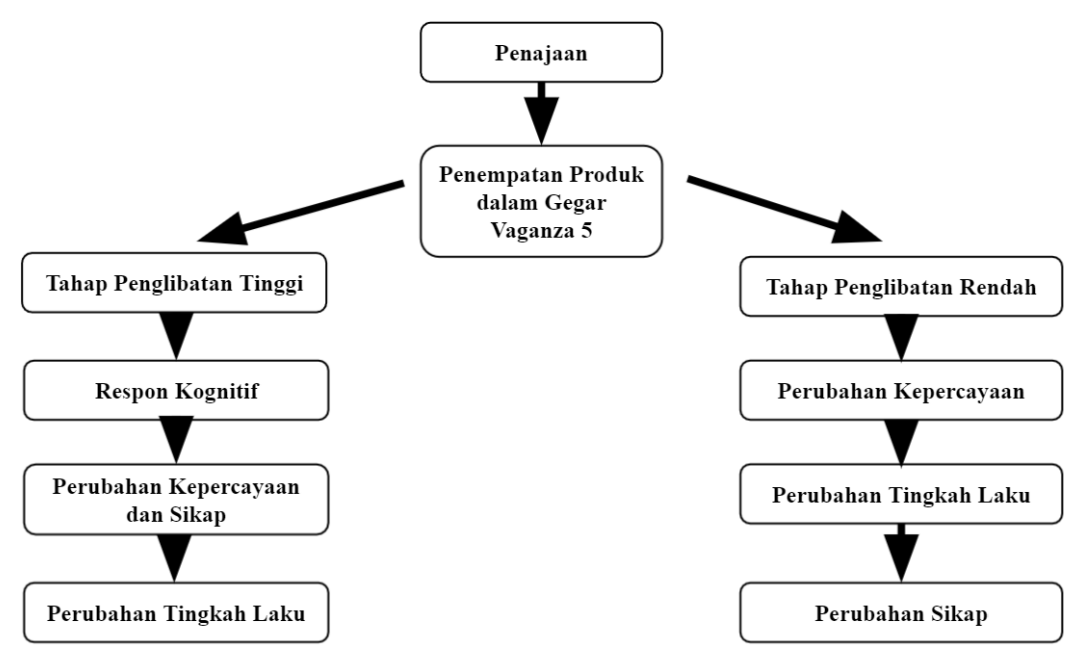

\section{Rajah 1: Model Kemungkinan Penguraian ( Diadaptasi dari Petty \& Cacioppo, 1986)}

Dalam proses central, kebiasaanya individu mempunyai tahap pengetahuan, motivasi dan minat yang tinggi terhadap sesuatu isu (Booth-Butterfield \& Welbourne, 2002). Proses ini berlaku apabila sesuatu mesej pemujukan adalah sangat penting terhadap penerima mesej tersebut (Bryant \& Oliver, 2009). Sebagai contoh, pengasas D’Herbs Holdings iaitu Dato' Aliff Syukri diberikan satu slot khas berdurasi 1 hingga 2 minit untuk menerangkan kebaikan produk keluarannya. Penonton yang mempunyai pengetahuan dan rasa minat terhadap barangan penjagaan diri akan terdorong untuk menilai dengan terperinci mesej pemujukan yang diterima.

Untuk proses peripheral, individu terbabit kurang mempunyai maklumat dan minat terhadap sesuatu isu. Oleh itu, tahap motivasi untuk menilai dengan mendalam mesej pemujukan yang diterima semakin berkurangan. Proses ini berlaku apabila isu yang cuba disampaikan tidak penting kepada individu yang menerima mesej tersebut dan menyebabkan individu tersebut kurang cenderung untuk memikirkan mesej pemujukan yang diterima. Dalam konteks yang tersendiri, kedua-dua laluan memainkan peranan mereka yang tersendiri. 
Oleh itu, ELM digunakan untuk mengenal pasti sama ada pengguna akan dipengaruhi dengan penempatan produk dan kesannya terhadap pembentukan sikap mereka. ELM juga dapat menjelaskan sejauh mana pengguna akan secara kognitif memproses produk yang diletakkan dan bukannya bilangan ulangan yang menentukan keberkesanan mesej pemujukan oleh produk untuk berlakunya perubahan sikap. Hal ini menjadikan mereka yang terlibat dalam aktiviti pemasaran menjadi semakin berminat dengan penempatan produk (Suhrbier \& Behring, 2016).

\section{Model Proses Persepsi}

Kajian ini juga akan mengadaptasikan model proses persepsi (Solomon et al., 2013) untuk memahami persepsi pengguna terhadap penempatan produk. Devito (2016) menyatakan proses persepsi terbahagi kepada lima peringkat iaitu rangsangan, menyusun, mentafsir dan menilai, memori dan mengingat semula. Pada peringkat pertama, organ deria seperti mata, telinga, hidung, jari atau mulut pengguna dirangsang seperti melihat orang sedang bermain gitar, makan buah-buahan atau menerima pesanan ringkas. Sesuatu yang baharu dan berlainan akan memberikan rangsangan dan menarik perhatian seseorang individu.

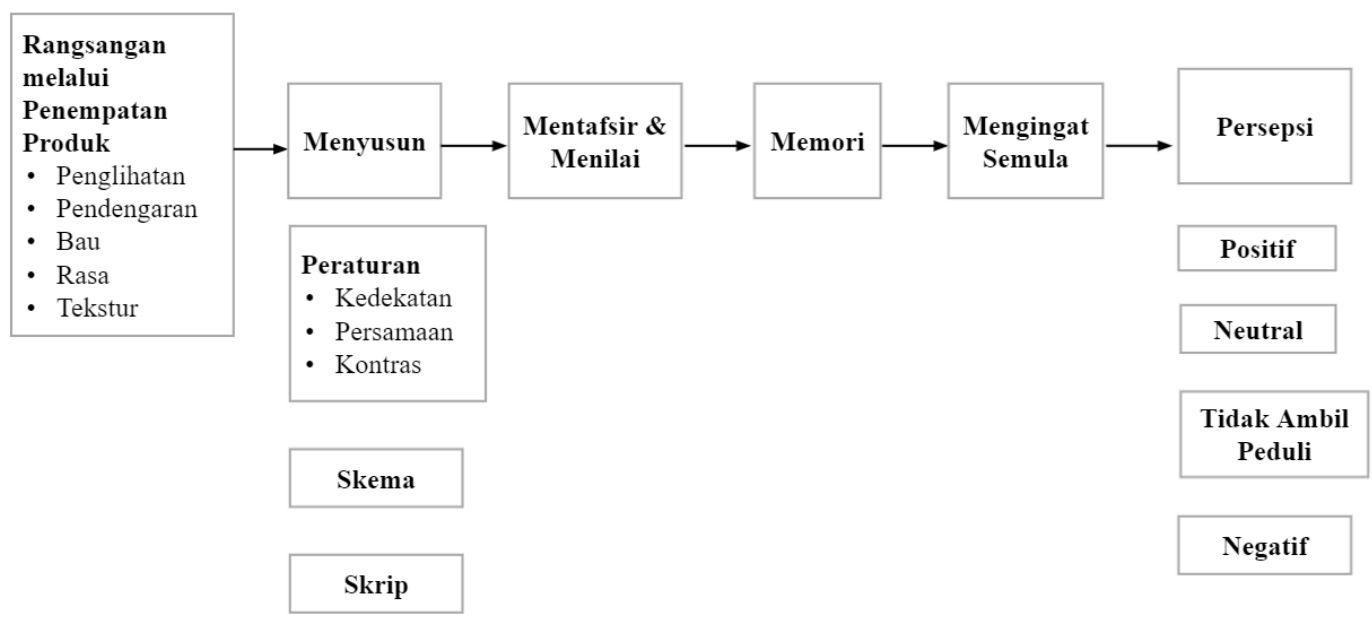

\section{Rajah 2: Model proses persepsi \\ (Diadaptasi daripada Devito, 2016)}

Pada peringkat kedua, individu menyusun maklumat yang diterima melalui organ deria menggunakan peraturan, skema dan skrip. Peraturan terbahagi kepada tiga iaitu kedekatan, persamaan dan kontra. Kedekatan adalah sesuatu perkara yang dekat dengan satu sama lain yang dikenali sebagai unit. Menyusun maklumat menggunakan skema adalah apabila individu mempunyai satu contoh mental yang membantu seseorang individu untuk menyusun berjuta-juta perkara atau maklumat setiap hari. Seterusnya, menyusun maklumat menggunakan skrip adalah maklumat tentang sesuatu perlakuan, acara atau prosedur. Peringkat ketiga pula adalah mentafsir dan menilai perkara yang dipengaruhi oleh pengalaman, keperluan, kehendak, nilai dan kepercayaan tentang bagaimana sesuatu perkara itu atau yang sepatutnya seperti jangkaan, keadaan fizikal, emosi dan lain-lain. Dalam 
erti kata lain, rangsangan yang diterima diberikan maksud yang tertentu bergantung pada seseorang individu itu. Seterusnya, persepsi serta tafsiran dan penilaian yang diletakkan ke dalam memori supaya dapat diambil semula apabila diperlukan. Kelima, mengingat kembali yang mana individu mengakses semula maklumat yang telah disimpan ke dalam memori.

Rangsangan yang diterima melalui penempatan produk ialah melalui penglihatan dan pendengaran sahaja iaitu apabila jenama dan produk dipersembahkan di dalam rancangan Gegar Vaganza musim ke-5 sama ada ketika berada di atas meja juri, melalui iPad dan juga slot khas oleh penaja. Adaptasi model proses persepsi ini hanya akan menggunakan rangsangan melalui penglihatan dan pendengaran dan mengabaikan rangsangan melalui bau, rasa dan tekstur kerana penonton tidak akan mendapat rangsangan melalui ketiga-tiga rangsangan tersebut. Model proses persepsi yang digunakan meliputi teori yang cukup untuk memenuhi matlamat tujuan pengkaji (Sila lihat Rajah 2).

\section{METODOLOGI KAJIAN}

Dalam penyelidikan ini, kaedah kualitatif digunakan untuk meneroka jenis penempatan produk yang digunakan dalam Gegar Vaganza musim ke-5 dan persepsi pengguna terhadap penempatan produk oleh D'Herbs Holdings Sdn. Bhd. dalam rancangan tersebut. Kaedah kualitatif melibatkan analisis kandungan dan temu bual mendalam. Kaedah pertama yang digunakan ialah analisis kandungan rancangan Gegar Vaganza musim ke-5 untuk mengumpul data mengenai jenis penempatan produk yang digunakan oleh $\mathrm{D}^{\prime}$ Herbs dalam rancangan tersebut. Gegar Vaganza musim ke-5 mula ditayangkan di saluran 104 Astro Ria dan 123 Astro Ria HD pada 30 September 2018 (Shikin et al., 2018) hingga 18 November 2018 (Madiha, 2018). Setiap episod dimuat turun dari platform YouTube. Selanjutnya, kajian ini menganalisis setiap episod Gegar Vaganza musim ke-5 (tujuh episod keseluruhannya dan berdurasi dua jam setengah). Jenis-jenis penempatan produk ini perlu diketahui untuk mencapai objektif pertama kajian, yang kemudiannya akan digunakan untuk memahami proses pemujukan yang telah berlaku dalam mempengaruhi persepsi pengguna. Jenis-jenis penempatan produk ditentukan berdasarkan tiga jenis penempatan produk iaitu implisit, eksplisit bersepadu dan bukan eksplisit bersepadu (D'Astous \& Seguin, 1999). Kajian ini telah mencatatkan setiap jenis penempatan produk yang wujud dalam setiap episod Gegar Vaganza musim ke-5 ke dalam buku kod.

Kemudian, temu bual mendalam digunakan untuk mengumpul data dan mempelajari perspektif seseorang individu daripada satu atau beberapa tema (Hoglund \& Oberg, 2011). Temu bual merupakan perbualan dua hala yang bertujuan untuk mengumpul maklumat kajian (Chua, 2011). Temu bual yang digunakan ialah jenis semi-struktur berdasarkan soalan protokol yang telah disediakan. Sebelum temu bual dijalankan, informan diminta menonton episod Gegar Vaganza musim ke-5 yang mengandungi kesemua jenis penempatan produk yang wujud dalam rancangan tersebut. Setelah informan menonton video tersebut, temu bual mendalam telah dijalankan. Soalan temu bual dibina berdasarkan komponen dari model kemungkinan penguraian oleh Petty dan Cacioppo (1986).

Informan penyelidikan ini dipilih dengan menggunakan teknik pensampelan bertujuan untuk mendapatkan maklumat terperinci berkaitan isu penempatan produk. Temu bual ini melibatkan lapan orang informan yang berumur di antara 21 hingga 30 tahun di Pulau Pinang. Lokasi kajian ini dipilih berdasarkan kedudukan Pulau Pinang yang menjadi pusat masyarakat pengguna dan kegiatan kepenggunaan yang aktif (Hilton, 2008). Informan ini 
dikenal pasti sebagai pengguna yang dapat menentukan keperluan atau keinginan diri, membuat pembelian dan kemudian melupuskan produk semasa tiga peringkat dalam proses penggunaan (Solomon et al., 2013). Penyelidikan ini mengenal pasti individu yang berbangsa Melayu sebagai sampel penyelidikan dan rasionalnya adalah kerana Gegar Vaganza musim ke-5 merupakan rancangan realiti televisyen yang menggunakan medium bahasa Melayu dan disasarkan kepada rakyat Malaysia yang berbangsa Melayu. Selain itu, informan harus menjadi salah seorang penonton rancangan Gegar Vaganza musim ke-5. Dapatan dari temu bual yang dijalankan ke atas lapan orang informan ini mendapati tahap ketepuan telah dicapai kerana tiada data baru ataupun yang relevan untuk diekstrak.

Kajian ini menggunakan analisis tematik induktif untuk menganalisis data temubual mendalam yang telah diperoleh. Analisis tematik induktif adalah apabila sedikit atau tiada teori, struktur atau rangka kerja digunakan untuk menganalisis data, sebaliknya data yang sebenar yang diterima digunakan untuk memperoleh struktur analisis. Penyelidikan ini membentuk tema berdasarkan prosedur yang disarankan oleh Braun dan Clarke (2006) melalui fasa-fasa berikut: memahami data, penjanaan kod permulaan, mencari tema, mengkaji semula tema, mentakrifkan dan menamakan tema serta menghasilkan laporan akhir.

\section{DAPATAN KAJIAN}

Bahagian ini akan membentangkan dapatan kajian yang diperoleh kepada dua bahagian iaitu jenis penempatan produk dalam Gegar Vaganza musim ke-5 dan persepsi pengguna.

\section{Jenis Penempatan Produk dalam Gegar Vaganza 5}

Analisis kandungan rancangan realiti televisyen Gegar Vaganza musim ke-5 telah dilaksanakan untuk menjawab objektif pertama kajian. Tiga jenis penempatan produk: implisit, eksplisit bersepadu dan bukan eksplisit bersepadu (D'Astous \& Seguin, 1999) telah digunakan untuk mengekod jenis penempatan produk yang digunakan dalam rancangan ini. Penempatan produk implisit adalah penempatan produk yang pasif, secara tidak rasmi dan tidak memaparkan kebaikan produk di dalam kandungan sesebuah rancangan televisyen. Penempatan produk eksplisit bersepadu ialah penempatan jenama atau logo yang dipaparkan secara aktif dan rasmi serta mempamerkan dengan jelas kelebihan produk dalam kandungan media. Selain itu, penempatan produk bukan eksplisit bersepadu ialah apabila jenama atau logo ditunjukkan dari permulaan, pertengahan dan akhir rancangan tetapi tidak digabungkan ke dalam rancangan.

\section{Penempatan Produk Implisit}

Dapatan kajian menunjukkan jenis penempatan yang paling ketara dan banyak digunakan dalam Gegar Vaganza musim ke-5 ialah penempatan produk implisit. Penempatan produk implisit adalah penempatan produk yang pasif apabila plak logo D’Herbs diletakkan di atas meja berdekatan dengan juri-juri. Jenama tersebut dipaparkan tanpa demonstrasi yang jelas tentang kelebihan atau kebaikan produk. Plak logo penaja utama, D'Herbs juga dapat dilihat dengan penaja bersama iaitu Cuckoo dan Adabi yang ditayangkan dalam iPad dan diletakkan berdekatan para juri. Pada minggu pertama, terdapat produk yang diletakkan di antara juri iaitu produk P'Pink Collagen. Pada minggu yang seterusnya, dari minggu kedua hingga ketujuh, hanya plak logo dan paparan logo D’Herbs melalui iPad yang dapat dilihat. 
Penggunaan penempatan produk implisit ini dianggap pendekatan yang strategik melalui perletakkan logo dan produk di antara para juri. Ia adalah bersesuaian dan memberikan pendedahan penajaan D'Herbs yang ketara kerana Gegar Vaganza musim ke-5 merupakan rancangan berbentuk pertandingan. Walau bagaimanapun, rancangan ini dilihat adakalanya menyekat pendedahan logo D'Herbs supaya tidak terlalu terdedah dengan menggunakan teknik kamera close-up yang hanya memfokuskan kepada muka juri dan penyanyi pada masa yang sama.

\section{Penempatan Produk Eksplisit Bersepadu}

Kajian ini juga mendapati pada setiap minggu tayangan Gegar Vaganza musim ke-5 diadakan, terdapat dua kali penempatan produk jenis eksplisit bersepadu yang diselitkan ke dalam kandungan rancangan selama beberapa minit. Penempatan produk eksplisit bersepadu merupakan penempatan jenama ataupun logo dalam rancangan secara rasmi dan aktif. Kelebihan dan kebaikan produk dinyatakan dengan jelas apabila pengasas D'Herbs Holdings, Dato' Seri Aliff Syukri, mendapat slot khas selama lebih kurang dua minit untuk mempromosikan produk keluaran syarikatnya. Pada setiap minggu, beliau akan memperkenalkan produk dengan melakukan demonstrasi produk terhadap individuindividu terpilih seperti juri tetap, pengacara dan lain-lain untuk memaparkan kebaikan produk di samping menambahkan maklumat terperinci mengenai produk seperti harga dan tempat untuk mendapatkan produk.

Slot penempatan produk eksplisit bersepadu ini dinamakan Abang Bawang yang bertujuan untuk menyelesaikan isu-isu yang timbul dan disuarakan oleh warga net di laman media sosial pengasas tersebut. Namun, Dato' Seri Aliff Syukri bijak dalam menggunakan peluang dengan mempromosikan produk-produknya. Sebagai contoh, pada slot Abang Bawang minggu kedua, pengasas tersebut menyatakan bahawa,

"Harganya seratus sembilan belas ringgit boleh dapat dekat GoShop pusat membeli belah...nombor satu Malaysia. Ni untuk Tok... Tok Ram. Aku nervous... Okey... Ini nak bagi putih bagi Datin Alyah bertambah sayang, luar cantik dalam cantik..."

Contohnya, pada minggu keempat pula, slot Abang Bawang memaparkan,
"Jadi yang mana kulit gelap ya, dengan saya punya sabun ni, dalam masa 24 jam yang kulit berkerak, kulit gelap inshaAllah jadi cerah... harga dia hanya seratus sembilan belas ringgit sahaja. Boleh didapati di GoShop..."

Maka, dapat dilihat bahawa pengasas produk menggunakan slot penajaan semaksimum yang mungkin tanpa membazir setiap saat yang diberikan. Penemuan penyelidikan juga menunjukkan bahawa penempatan produk jenis bukan eksplisit bersepadu tidak digunakan dalam rancangan Gegar Vaganza musim ke-5. 


\section{Persepsi Pengguna terhadap Penempatan Produk dalam Gegar Vaganza 5}

Persepsi merupakan cara seseorang individu memahami dunia dan proses bagaimana individu tersebut sedar akan objek, acara dan individu lain melalui deria seperti penglihatan, bau, rasa, sentuhan dan pendengaran (Devito, 2016). Berdasarkan analisis transkrip temubual, tiga tema utama dibentuk: persepsi neutral, positif dan negatif. Ketiga-tiga tema ini memberikan pemahaman yang mendalam mengenai persepsi pengguna terhadap penempatan produk berdasarkan jenis penempatan produk dalam program Gegar Vaganza.

\section{Persepsi Neutral}

Berdasarkan dapatan, kebanyakan informan mempunyai persepsi yang neutral terhadap penempatan produk atau jenama dalam rancangan Gegar Vaganza 5. Informan menyatakan tujuan mereka menonton rancangan tersebut kerana adanya watak atau individu yang diminati dalamnya. Penemuan ini menjelaskan walaupun penonton sedar dengan kewujudan perletakkan jenama di dalam rancangan tersebut, namun, oleh kerana penglibatan informan adalah pada tahap yang rendah, informan kurang memberikan perhatian terhadap mesej yang telah disampaikan. Maka, informan lebih bergantung kepada elemen-elemen lain dalam rancangan seperti watak, kualiti rancangan televisyen dan jalan cerita yang dipaparkan. Informan 2 menyatakan bahawa,

Selalunya kalau dari segi jalan cerita rancangan realiti TV itu benda dah boleh dijangkakan dah macam mana. Cuma saya suka kandungan dia la, kualiti dia terutamanya macam Gegar Vaganza, kebanyakan orang-orang lama tau yang mana yang dah tak menyanyi atau yang masih cam suam-suam kuku so dorang memang ada bakat ada suara dorang sendiri tau so memang saya minatlah lagipun memang saya pun dengar jugak lagu-lagu lama berbanding lagu-lagu sekarang ni.

(Informan 2, 6 Oktober 2019)

Berdasarkan ulasan informan 2, beliau mempunyai persepsi yang neutral terhadap penempatan produk yang dipaparkan dalam rancangan tersebut. Pada pandangan informan ini, beliau lebih memfokuskan kepada bakat penyanyi yang bertanding dalam program tersebut dan tidak begitu sedar dengan kewujudan penempatan produk D'Herbs. Menurut beliau, tujuan utama beliau menonton rancangan ini adalah untuk menghiburkan diri dengan lagu-lagu yang dipertandingkan. Maka, semasa menonton program ini, pengiklanan atau pemaparan produk tidak dapat mengambil perhatian beliau untuk bertindak ke arah mengingatinya kembali ataupun pembelian. Maka, beliau tidak dapat menafsirkan maklumat produk yang dipaparkan serta tidak dapat mengekalkan maklumat ini di dalam diri atau memori. Hal ini secara tidak langsung menunjukkan beliau melalui tahap penglibatan yang rendah untuk mengubah kepercayaan, tingkah laku atau sikap beliau terhadap produk yang ditempatkan dalam rancangan tersebut.

\section{Persepsi Positif}

Berdasarkan penyelidikan ini, dua subtema dibentuk, iaitu kesan mengingat kembali produk dan meningkatkan pemahaman tentang produk. 


\title{
Mengingat Kembali Produk
}

Dapatan kajian ini juga memaparkan penempatan produk implisit mendapat persepsi yang positif dari para informan untuk mengingat kembali produk. Hal ini berlaku apabila produk ataupun logo ditayangkan berulang kali dalam rancangan, secara tidak langsung ia akan melekat dalam minda pengguna. Kaedah ini menyebabkan berlakunya respon kognitif yang positif terhadap maklumat yang diterima.

Informan juga berpendapat bahawa pemilihan tempat dalam menempatkan produk di dalam Gegar Vaganza musim ke-5 adalah sangat strategik kerana produk ataupun logo diletakkan di antara para juri. Apabila juri memberikan komen kepada peserta, ia secara tidak langsung mendedahkan logo ataupun produk D'Herbs dan seterusnya menanam imej tersebut di dalam minda pengguna. Mengikut pendapat Informan 7,

\begin{abstract}
Ya. Bagi saya dia boleh memberi impaklah sebab kita manusia bila kita tengok benda tu berulang-ulang kali dia akan melekat kat dalam minda kita. Tambah pulak kita manusia, otak manusia ni kan dia kita akan mudah ingat gambaran kalau kita tengok je benda tu ulang-ulang kali dekat contohnya dekat iPad dia lepas tu dekat atas meja so kita akan ingat oh produk ni dalam rancangan realiti ni, mesti produk ni, bila tengok ulang-ulang kali kita bila kita lalu je kita akan nampak eh pernah tengok ah produk ni senang ingatlah. Secara amnya dia mudah, mudah terpahat dalam fikiran bila tengok ulang-ulang kali ni.
\end{abstract}

(Informan 7, 6 Oktober 2019)

Berdasarkan hasil dapatan ini, informan ini berpendapat bahawa seseorang pengguna lebih mudah untuk mengingati sesuatu jenama atau produk apabila ditayangkan ulang kali dalam sesebuah rancangan. Seperti yang dinyatakan, pengulangan imej logo, nama sesebuah jenama atau produk dan pemaparan produk di dalam rancangan tersebut dapat merangsang deria pengguna (penglihatan dan pendengaran) ke arah penerimaan atau persepsi yang positif. Dengan menerapkan imej dan maklumat ini berulang kali dalam minda seseorang pengguna, keadaan ini dapat mendorong pengguna untuk mula menyusun dan menilai maklumat sama ada terdapat persamaan atau kedekatan yang boleh dihubungkan antara identiti, keperluan dan kehendak mereka dengan manfaat produk. Seterusnya, pengguna akan mula mengakses maklumat dalam memori untuk mengingati kembali nama jenama dan produk yang dipaparkan dalam rancangan Gegar Vaganza.

Informan 7 juga berpendapat sedemikian kerana telah melalui tahap penglibatan yang tinggi dengan penempatan produk D'Herbs yang dipaparkan dalam rancangan tersebut. Apabila penglibatan yang memberangsangkan berlaku, ia mendorong kepada maklum balas kognitif yang positif antara pengguna dan membawa perubahan terhadap kepercayaan, sikap atau tingkah laku terhadap jenama atau produk tersebut.

\section{Meningkatkan Pemahaman Tentang Produk}

Selain itu, dapatan juga menunjukkan apabila informan menyaksikan sedutan rancangan Gegar Vaganza musim ke-5 yang memaparkan penempatan produk eksplisit bersepadu seperti Dato' Seri Aliff Syukri mempromosikan produk beliau, majoriti daripada informan merasakan bahawa ia memberikan maklumat mengenai produk keluaran D'Herbs secara langsung ataupun tidak langsung. Hal ini memberikan respons kognitif yang positif kerana terlihat tahap penglibatan tinggi antara khalayak dan pengasas jenama. Melalui penilaian 
ini serta keinginan informan untuk meningkatkan pengetahuan tentang produk yang dipamerkan, informan mempunyai persepsi yang positif terhadap penempatan produk eksplisit bersepadu. Berdasarkan Informan 1,

...contohnya macam D’Herbs tadi dia buat dekat Gegar Vaganza kan kalau saya sentiasa tengok Gegar Vaganza saya secara tak langsung... dia akan bagi saya info tentang produk-produk Aliff Syukri sebab saya percaya setiap minggu produk berbeza yang dia promote kan. Of course saya akan tahulah sebab selama ni saya memang tak tahu dia jual apa. Kadang-kadang kita just nampak sekali imbas tapi kita taktau produk dia macam mana, apa benda produk dia, berapa harga dia, kat mana saya nak dapatkan kan. So, bila Aliff Syukri guna Gegar Vaganza ni, saya secara tak langsung saya dapat sebab dia gunakan platform tu untuk memperkenalkan produk-produk dia. So, saya tahulah produk apa yang dia jual, untuk apa kegunaan dia....

(Informan 1, 6 Oktober 2019)

Informan 7 juga menyatakan yang beliau lebih memahami tentang produk-produk D'Herbs melalui pemasaran penempatan produk eksplisit bersepadu.

\begin{abstract}
“Betul... Saya rasa dia boleh menambahkan pengetahuan. Macam saya bagitahu tadi bila Dato' Aliff Syukri mempromosikan barang dia tadi, dia ada bagitahu pasal dia punya produk boleh beli dekat mana, pastu harga produk tu, kualiti produk tu, pastu dengan dia promosi kan. Kalau saya, ada produk baru produk serbuk arang tu saya tak tahu kalau dia tak bagitahu.
\end{abstract}

(Informan 7, 6 Oktober 2019)

Berdasarkan penemuan penyelidikan ini, Informan 1 dan 7 berpandangan sedemikian kerana beranggapan bahawa maklumat yang disampaikan oleh pengasas jenama dalam sesebuah rancangan televisyen dapat meningkatkan lagi pengetahuan beliau tentang produk yang dipamerkan. Dengan adanya pelbagai jenis produk dan jenama yang ditawarkan kepada pengguna di pasaran, pengguna tidak sedar dengan kewujudan sesetengah produk atau jenama tanpa didorong untuk mendapatkan maklumat tentangnya. Penempatan produk jenis eksplisit bersepadu yang digunakan oleh D'Herbs melalui penceritaan dan demonstrasi di slot Abang Bawang ini memberikan peluang kepada pengguna untuk mendapatkan maklumat lanjut tentang produk, manfaatnya serta cara-cara menggunakan produk tersebut. Melalui maklumat yang dikongsikan oleh pengasas, pengguna dapat menilai sama ada produk atau jenama adalah relevan untuk diri mereka. Selain itu, berdasarkan pandangan ini juga, informan-informan ini memberikan respons kognitif yang positif terhadap penempatan produk yang disampaikan yang membawa kepada perubahan kepercayaan terhadap produk. Ini merupakan suatu maklum balas yang memberangsangkan dalam mempengaruhi sikap dan tingkah laku pengguna ke arah niat pembelian dan pembelian sebenar.

\title{
Persepsi Negatif
}

Walau bagaimanapun, majoriti informan juga memberikan persepsi yang negatif terhadap niat pembelian terhadap produk D'Herbs. Terdapat beberapa faktor yang menyebabkan informan mempunyai persepsi negatif terhadap penempatan produk eksplisit bersepadu 
oleh D'Herbs. Antaranya adalah penerangan yang diberikan oleh Dato' Seri Aliff Syukri tidak begitu jelas dan demonstrasi yang dilakukan adalah tidak wajar. Sebagai contoh, apabila beliau mengatakan ingin memilih "the ugly woman" atau perempuan yang tidak cantik untuk menunjukkan kelebihan produk dan tanpa rasa malu menyentuh muka penonton dalam rancangan untuk menunjukkan kesan penggunaan produk beliau. Salah seorang informan berpendapat,

Tapi macam secara peribadi, pada saya, saya tak rasa lebih-lebih lagi bila dia menggunakan cara yang hinaan, saya rasa macam, impak ni ada tapi bukan impak positif la, namun lebih kepada impak negatif. Kita tahu produk dia untuk putih tapi sebab dia menggunakan cara hinaan tu saya rasa saya macam dia beri impak negatif pada pandangan saya sendiri.

(Informan 4, 6 Oktober 2019)

Seorang lagi informan bersetuju dan menyatakan,

Macam saya sebagai pelajar, saya didedahkan dengan penggunaan maklumat secara terbuka. Jadi macam saya mendapat maklumat tentang keburukan menggunakan serbuk arang untuk memutihkan gigi dah sebagainya tu jadi saya tak terkesanlah. Mungkin saya terkesan dengan iklannya tapi tidak berminat untuk mencubanya.

(Informan 5, 6 Oktober 2019)

Berdasarkan dapatan kajian, Informan 4 dan 5 berpendapat bahawa penggunaan penempatan produk eksplisit bersepadu oleh D'Herbs melalui slot Abang Bawang telah menyebabkan mereka mempunyai tanggapan yang negatif terhadap produk yang dipaparkan. Informan 4 berpandangan sedemikian kerana sikap dan tingkah laku yang ditunjukkan oleh pengasas jenama terhadap penonton (dengan cara menghina) adalah bertentangan dengan ajaran agama Islam dan budaya masyarakat Melayu. Sebagai seorang yang berpengaruh, pengasas seharusnya menampilkan imej yang bersih, berkelakuan sopan dan tidak keterlaluan dalam mempromosikan jenama atau produk. Apabila sikap yang negatif dipaparkan kepada pengguna, pengguna tidak dapat menghubungkaitkan diri dengan produk yang ditawarkan kerana ingin mengelakkan diri dari mempunyai kesamaan dengan sikap individu tersebut. Hal ini akan menyebabkan tiada perubahan yang akan berlaku terhadap niat pembelian pengguna.

Selain itu, Informan 5 pula berpendapat tingkah laku dan sikap beliau tidak akan berubah walaupun didedahkan kepada penempatan produk eksplisit bersepadu kerana wujudnya maklumat yang bercanggah dengan maklumat yang disampaikan oleh pengasas. Oleh kerana perbezaan fakta dan maklumat yang diperoleh, kredibiliti pengasas tidak dapat ditonjolkan dan hal ini menyebabkan persepsi yang negatif terbentuk terhadap produk tersebut. Kini, dengan wujudnya teknologi yang semakin berkembang dan kemudahan untuk mengakses maklumat di mana sahaja, pengguna mempunyai peluang untuk memahami sesuatu produk dan manfaatnya dengan lebih mendalam. Apabila maklumat bercanggah diantara satu sama lain, sudah pastinya pengguna tidak dapat memberikan kepercayaan terhadap produk yang dipaparkan. Oleh itu, pemasar atau pengasas yang ingin mempromosikan sesuatu produk memerlukan maklumat yang dapat menyokong hujahan yang diberikan agar pengguna dapat menilai dengan baik tentang manfaat produk terhadap diri mereka. 
Maka, tanggapan negatif ini membawa kepada tahap penglibatan yang rendah informan, mengurangkan kepercayaan mereka terhadap pengasas tersebut dan secara tidak langsung mempengaruhi informan ke arah sikap tidak suka atau negatif terhadap penempatan produk dan jenama. Kesimpulannya, penemuan menunjukkan persepsi pengguna terhadap penempatan produk yang digunakan oleh D'Herbs bergantung pada jenis penempatan produk dan kandungan yang dipaparkan. Terutamanya, penempatan produk implisit dan eksplisit bersepadu mendapat persepsi yang positif dalam meningkatkan tahap pengetahuan dan ingat semula pengguna terhadap produk dan jenama. Walau bagaimanapun, penempatan produk eksplisit bersepadu juga menyebabkan berlakunya persepsi negatif yang mempengaruhi niat pembelian dan tingkah laku pengguna.

\section{PERBINCANGAN}

Penemuan menunjukkan bahawa pengguna membentuk persepsi yang neutral terhadap penempatan produk D'Herbs kerana kurangnya stimulasi yang membuatkan mereka melalui perhatian yang terpilih (Devito, 2016). Pengguna menjelaskan bahawa mereka lebih menumpukan kepada watak dan jalan cerita yang dipaparkan dalam rancangan tersebut untuk memenuhi kehendak mereka iaitu minat mereka terhadap seseorang atau kandungan rancangan. Oleh yang demikian, pengguna tidak dapat menilai dan menginterpretasi mesej yang diberikan melalui penempatan produk untuk disimpan dalam memori dan diingat semula untuk bertindak ke arah perubahan sikap dan tingkah laku (Devito, 2016).

Berdasarkan Model Kemungkinan Penguraian, kandungan mesej melalui penempatan produk dalam rancangan ini melalui proses pemujukan peripheral. Pengguna menunjukkan tahap penglibatan kognitif yang rendah dan kurang berminat terhadap produk atau jenama yang dipaparkan kerana memfokuskan diri kepada watak dan jalan cerita. Maka, maklumat tersebut dianggap tidak penting untuk melalui tahap motivasi bagi menilai dengan mendalam mesej yang diterima untuk membentuk kepercayaan, perubahan tingkah laku atau sikap pengguna (Suraini, Hasrina \& Bahiyah, 2014).

Secara spesifik, dapatan kajian ini menunjukkan jenis-jenis penempatan produk dalam sesebuah rancangan realiti televisyen memainkan peranan yang penting dalam pembentukan persepsi pengguna terhadap produk yang dipaparkan. Jenis-jenis penempatan produk yang terdapat dalam rancangan realiti televisyen Gegar Vaganza musim ke-5 terbahagi kepada dua iaitu penempatan produk implisit dan eksplisit bersepadu. Penempatan produk secara implisit dapat dilihat apabila jenama D'Herbs diletakkan secara visual dengan ketara di antara para juri. Plak logo D’Herbs dan perletakkan logo dalam iPad yang ditempatkan berdekatan dengan juri ini dilakukan tanpa sebarang pertunjukan demonstrasi atau penerangan tentang kebaikan produk.

Berdasarkan penemuan kajian ini, perletakan produk secara implisit telah membawa kepada persepsi yang positif kerana pengguna dapat mengingat kembali produk yang disiarkan secara berulang kali tanpa sebarang demonstrasi, membantu penonton mengingat semula identiti jenama seperti logo, warna, pembungkusan, slogan dan sebagainya. Maka, apabila pengguna melalui kelima-lima tahap dalam proses persepsi iaitu stimulasi, organisasi, interpretasi-penilaian, memori dan ingat semula; pengguna melalui proses peripheral. Khususnya, pengguna berada pada tahap penglibatan kognitif yang rendah, afektif yang tinggi dan disertai tahap pemikiran dan pengetahuan yang kurang tentang produk (Suraini, Hasrina \& Bahiyah, 2014). Maka, kajian ini adalah selari dengan pandangan Van 
Reijmersdal et al. (2007) yang mendapati kekerapan pendedahan penempatan jenama melalui televisyen memberi kesan kepada imej jenama. Selain itu, penemuan ini juga sejajar dengan Bamimi et al. (2012) yang membincangkan bahawa kesan penempatan jenama dalam media menunjukkan rakyat Malaysia mempunyai tahap penerimaan dan ingat semula jenama yang tinggi, mempengaruhi corak tingkah laku pengguna.

Namun, dapatan ini bertentangan dengan kajian Law dan Braun (2000) yang mendapati keberkesanan strategi penempatan produk dalam visual akan menyebabkan produk paling kurang diingat semula namun lebih digemari oleh penonton. Homer (2009) juga mendedahkan produk ataupun logo yang ditonjolkan berulang kali mungkin memberikan pengaruh yang negatif terhadap sikap pengguna, namun penempatan produk yang dilakukan secara halus mempunyai pengaruh yang positif terhadap pengguna.

Di samping itu, kajian ini juga menunjukkan bahawa penempatan produk di dalam Gegar Vaganza musim ke-5 juga menggunakan penempatan produk eksplisit bersepadu. Rancangan tersebut telah memberikan satu slot, Abang Bawang, untuk pengasas D'Herbs, Dato' Seri Aliff Syukri bagi mempromosikan produknya secara rasmi dan aktif semasa rancangan berjalan. Dalam slot tersebut, pengasas mendemonstrasi penggunaan produk dan kelebihannya terhadap para penonton yang berada di studio rancangan. Ini memberi peluang kepada beliau untuk menyampaikan maklumat terperinci tentang produk-produk D'Herbs.

Penemuan menunjukkan apabila penempatan produk eksplisit bersepadu ditayangkan, pengguna melalui proses central dalam proses pemujukan kerana berada pada tahap penglibatan kognitif yang tinggi dengan pengetahuan yang meluas mengenai produk D'Herbs. Hal ini membawa kepada sesuatu mesej menjadi dekat dan penting untuk pengguna (Bryant \& Oliver, 2009), membentuk persepsi yang positif terhadap penempatan produk dalam meningkatkan pemahaman terhadap produk tersebut.

Namun, penempatan produk jenis ini juga menerima pandangan yang negatif daripada pengguna untuk bertindak ke arah membentuk niat pembelian. Menerusi beberapa slot Abang Bawang yang memaparkan demonstrasi penggunaan produk, cara pengasas berinteraksi dengan penonton untuk mempromosikan produknya memberikan tanggapan yang negatif terhadap jenama dan individu tersebut. Merujuk kepada elemen dalam model kemungkinan penguraian (Petty \& Cacioppo, 1986), pengalaman ini mempengaruhi kedalaman penguraian seseorang individu justeru mereka cenderung untuk memberikan persepsi yang negatif terhadap produk D'Herbs. Beberapa orang responden menyatakan pengetahuan mereka mengenai jenama ataupun produk kecantikan tidak akan menunjukkan hasil dalam masa yang singkat seperti yang ditunjukkan oleh pengasas. Oleh itu, mereka tidak berasa terpujuk dengan mesej yang disampaikannya melalui penempatan produk eksplisit bersepadu. Ini membuktikan penempatan produk berfungsi lebih baik untuk mengingat semula jenama, pengiktirafan jenama dan kesedaran jenama berbanding niat pembelian (Bressoud, Lehu \& Russell, 2010). Oleh itu, kajian ini seiring dengan kajian Tiwsakul, Hackley dan Szmigin (2005) yang mendapati pengguna merasakan penempatan produk jenis ini dapat meningkatkan kesedaran jenama.

Secara kesimpulannya, hasil kajian ini dapat menunjukkan bahawa jenis penempatan produk sebenarnya memainkan peranan yang penting dalam pembentukan persepsi. Bagaimanapun, pembentukan persepsi juga boleh dipengaruhi oleh beberapa faktor lain seperti watak dan tingkah laku seseorang yang menyampaikan mesej pemujukan tersebut. 


\section{CADANGAN DAN KESIMPULAN}

Berdasarkan perbincangan, penyelidikan ini membuktikan jenis penempatan produk mempengaruhi pembentukan persepsi pengguna terhadap produk yang dipaparkan. Walau bagaimanapun, kajian ini juga mempunyai beberapa batasan yang tersendiri. Pertama, kajian ini memfokuskan pengguna yang berumur antara 21-30 tahun sahaja yang mana dapatan tidak dapat digeneralisasikan kepada populasi negara. Maka, kajian pada masa hadapan boleh menyasarkan sampel yang lebih besar dari pelbagai lapisan umur dan status sosial yang berbeza untuk hasil yang lebih generalisasi.

Seterusnya, kajian ini memfokuskan kepada penempatan produk yang dilakukan secara spesifik oleh D'Herbs Holdings Sdn. Bhd. yang mana hasil kajian ini tidak dapat digeneralisasikan pada semua organisasi yang bercadang menggunakan kaedah penempatan produk. Aspek ini perlu dipertimbangkan untuk memfokuskan kepada sektor rancangan realiti televisyen yang lebih luas. Tambahan lagi, kajian ini memfokuskan kepada pasaran di Malaysia yang mana pertandingan nyanyian banyak dihasilkan oleh stesen-stesen televisyen di Malaysia, bagaimanapun ia tidak bermakna ia adalah sama seperti di negara-negara lain. Adalah amat menarik sekiranya kajian merentasi budaya dapat dilakukan untuk melihat persepsi pengguna terhadap penempatan produk.

Akhir sekali, kajian masa hadapan juga boleh dilakukan terhadap tahap kredibiliti yang pengguna yang dikaitkan dengan penggunaan media yang berlainan seperti filem, permainan video, muzik video dan lain-lain. Hal ini akan membolehkan organisasi atau pemasar memahami bagaimana pengguna bergantung pada media ini dan seterusnya akan membantu mereka dalam pemilihan media yang efisien untuk menempatkan produk mereka.

\section{RUJUKAN}

Allen, S. (2010). How to become successful at sponsorship sales. Trafford, Victoria.

Baharom, B. (2016, Januari 23). Vida Beauty teruskan tajaan walaupun berdepan ujian. BH Online. Diakses daripada https://www.bharian.com.my/node/117322

Bamini, K., Balakrishnan, Azlinda Shazneem, M. S., Dousin, O. \& Yukthamarani, P. (2012). The impact of brand placement and brand recall in movies: empirical evidence from Malaysia. International Journal of Management and Marketing Research, 5(2), 39-52.

Boerman, S. C., Van Reijmersdal, E. A., \& Neijens, P. C. (2013). Appreciation and effects of sponsorship disclosure. Dlm. Sara Rosengren, Micael Dahlén \& Shintaro Okazaki (eds.) Advances in Advertising Research, IV, (h. 273-284). Gabler, Wiesbaden: Springer.

Braun, V. \& Clarke, V. (2006). Using thematic analysis in psychology. Qualitative Research in Psychology, 3(2), 77-101.

Brennan, I., Dubas, K. M., \& Babin, L. A. (1999). The influence of product-placement type \& exposure time on product-placement recognition. International Journal of Advertising, 18(3), 323-337.

Bressoud, E., Lehu, J. M., \& Russell, C. A. (2010). The product well placed: The relative impact of placement and audience characteristics on placement recall. Journal of Advertising Research, 50(4), 374-385.

Bryant, J., \& Oliver, M. B. (Eds.). (2009). Media effects: Advances in theory and research. Routledge.

Cain, R. M. (2011). Embedded advertising on television: Disclosure, deception and free speech rights. Journal of Public Policy \& Marketing, 30(2), 226-238. 
Campbell, M. C., Mohr, G. S., \& Verlegh, P.W. J. (2007). Effects of product placement and sponsorship disclosure: A flexible correction approach. Paper presented at the International Conference on Research in Advertising, Lisbon, Portugal.

Chua, Y. P. (2011). Kaedah penyelidikan: Buku 1 (2nd ed.). McGraw Hill.

Cornwell, T. B., \& Maignan, I. (1998). An international review of sponsorship research. Journal of advertising, 27(1), 1-21.

Cowley, E., \& Barron, C. (2008). When product placement goes wrong: The effects of program liking and placement prominence. Journal of Advertising, 37(1), 89-98.

D'Astous, A. \& Séguin, N. (1999). Consumer reactions to product placement strategies in television sponsorship. European Journal of Marketing, 33 (9/10), 896-910.

Devito, M. (2016). Attitudes Toward and Perceptions of Deer Management in Suburban Boston (Doctoral dissertation) Brandeis University.

Erdogan B. Z., \& Kitchen, P. J. (1998). Managerial mindsets and the symbiotic relationship between sponsorship and advertising. Marketing Intelligence \& Planning, 16 (6), 369-374.

Flavettes Malaysia. (2018, Disember 20). Pujaan Hati Kanda brought to you by Flavettes Effervescent Glow [Fail Video]. Diakses daripada https://www.youtube.com/ Dimuat turun pada 18 Januari 2020.

Gupta, P. B., \& Lord, K. R. (1998). Product placement in movies: The effect of prominence and mode on audience recall. Journal of Current Issues E Research in Advertising, 20(1), 47-59.

Gutnik, L., Huang, T., Lin, J. B. \& Schmidt, T. (2007). New trends in product placement. Acedemia. Diakses daripada http://www.academia.edu/download/32362617/D-placement. doc Dimuat turun pada 18 Januari 2020.

Gritten, A., 2007. Media proliferation and the demand for new forms of research. International Journal of Market Research, 49(1), 15-23.

Hanisah, S. (2019, Januari 31). Pujaan Hati Kanda raih 12 juta tontonan. BHOnline. Diakses daripada https://www.bharian.com.my/

Hilton, M. (2008). The death of a consumer society. Transactions of the Royal Historical Society, 18, 211-236.

Hoglund, K., \& Oberg, M. (2011). In-depth interviewing: The process, skill and ethics of interviews in peace research KAREN BROUNÉUS. Dlm. Understanding Peace Research (pp. 142-157). Routledge.

Homer, P. M. (2009). Product placements. Journal of Advertising, 38(3), 21-32.

Imang, U. (2015). Sifat dan motivasi penontonon filem dalam kalangan penonton filem di Malaysia. Jurnal Komunikasi Borneo. Edisi Khas (Konvokesyen Ke-17 UMS), 47-65.

Karisik, V. J. (2014). 20 Years of research on product placement in movie, television and video game media. Journal of Economic and Social Studies, 4(2), 253 - 283..

Karrh, J. A., McKee, K. B., \& Pardun, C. J. (2003). Practitioners' evolving views on product placement effectiveness. Journal of Advertising Research, 43(2), 138-149.

Koekemoer, L. (2004). Marketing communications. Juda Academic.

Kunh, K. A. (2008). The impact of brand and product placements in electronic games (Doctoral Dissertation). Diakses daripada https://www.smbs.at/Dimuat turun pada 25 Januari 2020.

Law, S., \& Braun, K. A. (2000). I'll have what she's having: gauging the impact of product placements on viewers. Psychology E Marketing, 17(12), 1059-1075. 
Liew, C. K. \& Lim, E. Q. P. (2014). The effectiveness of product placement: The influence of product placement towards consumer behavior of the millennial generation. International Journal of Social Science and Humanity, 4(2), 138-142.

Madiha, A. (2018, November 18). Gegar Vaganza 5: Noryn Aziz tepati ramalan, dinobat juara. Astro Awani. Diakses daripada http://www.astroawani.com

Mohd Amir, S. M. N. \& Shahrel, N. B. (2018). A study on awareness of product placement in malaysian movies. Idealogy, 3(2), 235-242.

Nurul Hanani, O., Jalilah, J. S.\& Nur Widad, R. (2017, Mac). The effects of product placement in Malaysian movies and its influence on consumer behavior. Paper presented at The Asian Conference on Arts \& Humanities 2017, Kobe, Japan.

Petty, R.E. \& Cacioppo, J.T. (1986). Communication and persuasion: Central and peripheral routes to attitude change. Springer-Verlag.

Shikin, H., Aida Rizmariza, K. \& Ruhaya, A. H. (2018, September 24). Gegaran GV5. Utusan Online. Diakses daripada http://www.utusan.com.my/

Suhrbier, A., \& Behring, T. K. (2016). Product placement in reality television: Consumer's perception and attitude change towards product placement in a German baking show. (Master's dissertation), International Business School, Jonkoping University.

Suraini, G., Hasrina, M. \& Bahiyah, O. (2014). Kesan drama hibur-didik dan dokumentari dalam mempengaruhi niat untuk menderma organ: Satu eksperimen berteraskan Model Elaboration Likelihood. Jurnal Komunikasi, 30(2), 1-20.

Solomon, M., Bamossy, G., Askegaard, S., \& Hogg, M. (2013). Consumer behaviour: A European perspective (5th ed). Pearson.

Speck, P. S., \& Elliott, M. T. (1997). Predictors of advertising avoidance in print and broadcast media. Journal of Advertising, 26(3), 61-76.

Tiwsakul, R., Hackley, C., \& Szmigin, I. (2005). Explicit, non-integrated product placement in British television programmes. International Journal of Advertising, 24(1), 95-111.

Van Reijmersdal, E. A., Neijens, P. C., \& Smit, E. G. (2007). Effects of television brand placement on brand image. Psychology \& Marketing, 24(5), 403-420.

Van Reijmersdal, E., Smit, E., \& Neijens, P. (2010). How media factors affect audience responses to brand placement. International Journal of Advertising, 29(2), 279-301.

Van Reijmersdal, E. A., Tutaj, K., \& Boerman, S. C. (2013). The effects of brand placement disclosures on skepticism and brand memory. Communications-The European Journal of Communication Research, 38(2), 127-146.

Van Zyl, J. (2016). The impact of product placement on consumer involvement in the South African automotive industry (Unpublished Doctoral dissertation), University of the Free State.

Woelke, J., \& Steininger, C. (2008). Separating TV ads from TV programming: What we can learn about program-integrated advertising from economic theory and research on media use. Communications, 33(4), 455-471. 